УДК 336.7: 519.8

\author{
T. Tokarchuk, H. A. Bartelet
}

\title{
UNLEASHING UKRAINE'S ECONOMIC POTENTIAL: MACROECONOMIC MULTIPLIERS FROM A FEEDBACK PERSPECTIVE
}

The purpose of the research is the empirical analysis andelaboration of the system dynamics approach to define and estimate the key drivers of the future macroeconomic stabilization and economic potential of the Ukrainian economy. The study used thegeneralization, systematization and grouping of data, methods of system analysis and synthesis as well as the system dynamics methods and models.

Research results. The analysis of the development of the Ukrainian economy in comparison to the Polish economic situation has been completed. We confirmed the hypothesis that many of the initial economic problems in Ukraine - such as a low aggregate demand and export competitiveness - have been the cause of the exchange rate regime. Elaborated system dynamics models not only allow to analyze the feedback structure of a national economy but can also be used to verify the effectiveness of the different implications for the economic policymaking in Ukraine in the coming years.

The results of this paper are mostly exploratory and need further, deeper research before conclusions can be used for policymakers in order to elaborate the economic strategy which leads to improvement of the economic potential of Ukraine in the short and long run.

Conclusions. Based on the empirical analysis conducted on the realization of the two types of the system dynamic models with the focus on explaining the interrelationships between domestic consumption, aggregate demand, inflation, export competitiveness, and exchange rate fluctuations, it was shown that although the currency peg has had a positive impacts on Ukraine's energy imports, many of the other economic problems in Ukraine, such as a low aggregate demand and export competitiveness, have had place. It was also confirmed that the passage to flexible exchange rate regime is one of the important drivers of the economic potential and the competitiveness reinforcing as well as achievement of macroeconomic stabilization, especially in the long run.

Keywords: economic policy,macroeconomic stabilisation, macroeconomic indicators, exchange rate regime, system dynamics methods

\section{JEL classification: E17, E52, C15, C53}

Introduction and research problem. After decades of being a relatively unknown country among European and American policymakers, Ukraine has become one of the most bespoken countries within Europe and the world in recent years. Unfortunately, most of the attention has quite a negative character, including the economic situation, migration problems, macroeconomic instability, and increasing corruption in the recent time. What is still lacking is fundamental knowledge about the country itself, among others about its economy, especially about its economic potential and perspectives of the macroeconomic stabilization. This is why analysis of the main challenges and opportunities that Ukraine has faced in recent years and will face in the years to come as well as the investigation of the key factors of the future macroeconomic stabilization and economic potential still very important for further deeper research. The other popular discussed problem concerns the passage to flexible exchange regime instead of fixed one by National bank of Ukraine.This can be consider as the effective macroeconomic driver of the economic and financial stabilizationalso need of the deeper investigation and improvement with using of the adequate mathematical tools including system dynamics methods.

Resent publications analysis. The problem of the economic potential and perspectives of the economic growth for the emerging countries as well as a discussion about different kinds of the exchange rate regime as the macroeconomic driver for different countries in different periods of their economic development has been investigated by many foreign and Ukrainian researchers, including O. Faryna, Y. Gorodnichenko, G. Roland, D. Romer, M. Schnitzer, V. Heits, I. Lukianenko, V. Melnychuk, S. Nikolaychuk, L. Shavalyuk, S. Shumska, M. Skrypnychenko, and others $[1-4,7-10]$. It should be 


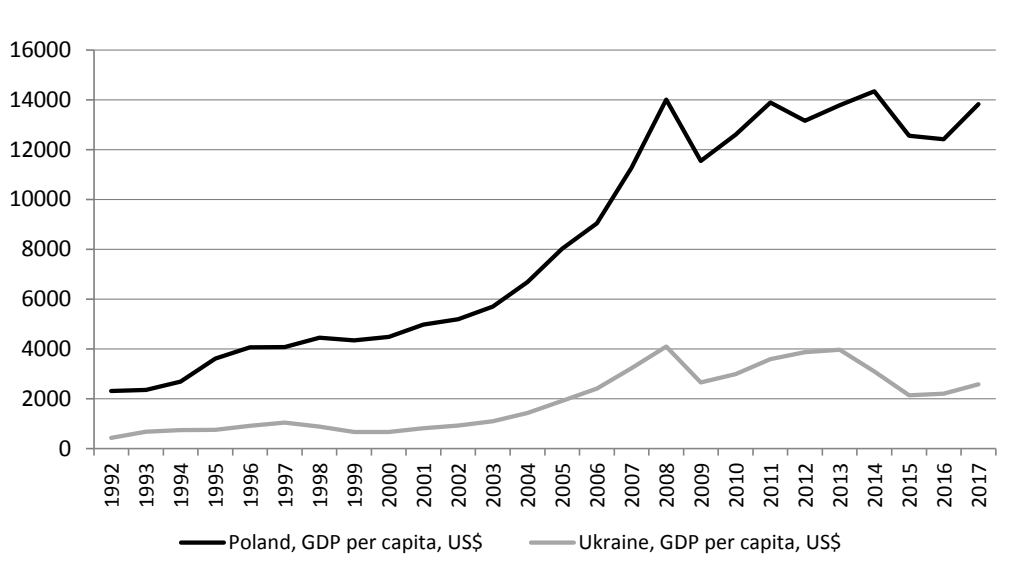

Fig. 1. GDP per capita Ukraine vs. Poland during 1992-2017 (Source: WEO database, IMF)

behind. Figure 1 shows the GDP per capita in both Ukraine and Poland from 1992-2017.

Having gained independence from the Soviet Union in 1991, Ukraine expectedly had large problems in transitioning from a mostly centrally planned economy to a market economy. This led to a period of 'hyperinflation' in 1992-1993 followed by the largest economic downturn in the history of Ukraine (real GDP fell by 23 percent in 1994) [7, p. 8]. In August 1996, Ukrainian Hryvnia was introduced as the official national currency in

mentioned that most of foreign scientists in their researches have been focused mainly on the developed countries, as well as on the emerging countries with economic growth faster than Ukrainian economy $[2,8]$. The investigation of the Ukrainian scientists in many cases was based on complicated macroeconometrics models aimed to estimate the relationship among the macroeconomic indicators in different sectors of Ukrainian economy. These papers have been mostly focused on the scenario analysis of the behaviour of the whole economy with the objective to elaborate the most effective strategy of the macroeconomic stabilisation under rising external and internal risks and political shocks under different exchange rate regimes $[3,10]$.

Unsolved parts of the problem. The analysis of the research papers of Ukrainian and foreign researchers has shown that the elaboration of an adequate model to confirm the necessity of introducing a flexible exchange regime as an important driver of the financial stability and economic growth continue to be very significant.

Research goal and questions. The purpose of the research is the empirical analysis of the key factors of the future macroeconomic stabilization and economic potential of the Ukrainian economy, as well as elaboration of the system dynamics modelling to prove the hypothesis that many of the initial economic problems in Ukraine, such as a low aggregate demand and export competitiveness, have been a cause of the exchange rate regime.

Main findings. The estimation of Ukrainian most effective macroeconomic multipliers is interesting in comparison with other emerging countries with similar starting conditions. As a country from the former Soviet-block, Ukraine is best compared to Poland in terms of its size, population, and development. If we compare economic progress in Ukraine with that in Poland, it becomes clear that Ukraine is currently far
Ukraine with the exchange rate of around 2 Hryvnia/US\$. In 1998, due to the combination of fiscal crisis, a slowdown in structural reforms, and a decreased investor confidence in emerging markets following the Russian and Asian economic crisis, the Ukrainian hryvnia devalued and its exchange rate fell to around 5 Hryvnia/US\$ in 2000. Combined with the general worldwide economic upturn following the Millennium (i. e. the year of 2000), the devaluation of the hryvnia led to a growing competitiveness of the Ukrainian economy. Profits of export industries (mainly steel and machineries) soared, and the real GDP growth reached $+9 \%$ in 2001. On average, Ukraine recovered $8 \%$ of GDP growth per year between 2000 and 2004. This was higher than in Central and Eastern Europe (including Poland) where the average growth was around $4 \%$ per year. However, as can be inferred from Figure 1, Ukraine's growth came from a much smaller base than that of, for example, Poland. In 2000, the Ukrainian government also made the decision to (administratively*) peg the value of the hryvnia to that of the US\$, at the exchange rate of 5 hryvnia/US\$. When macroeconomic conditions worsened in Ukraine in 2005 and its GDP growth decelerated. Because of the peg of the hryvnia to the US\$, the exchange rate of the hryvnia was not able to reflect the worsening of Ukraine's competitive position [7]. Figure 2 shows how Ukraine's current account rapidly worsened in 2005, mainly as the result of the uncompetitive exchange rate of the hryvnia. Another reason for the imbalance was the rapid increase in foreign capital inflows after the "Orange Revolution" in 2004, which led to growth of consumption imports financed by the debt capital.

* The official term was a 'managed floating exchange rate', but in reality the exchange was not really allowed to float. 
This situation continued until the financial crisis of 2008 , when the peg to the US\$ was finally devalued to around 8 hryvnia/US\$. This devaluation eventually did not prove strong enough. Following the Ukrainian revolution of 2014 , the political turmoil led to a shortage of foreign exchange reserves coupled with a loss of financing from both the Russian Federation and international markets. The political shakeup and severe confidence crisis caused a sharp reversal in private capital inflows in 2014. In these circumstances, access to the external capital market by the private sector was effectively closed. The level of international reserves fell to a critically low level of US\$ 7.5 billion,

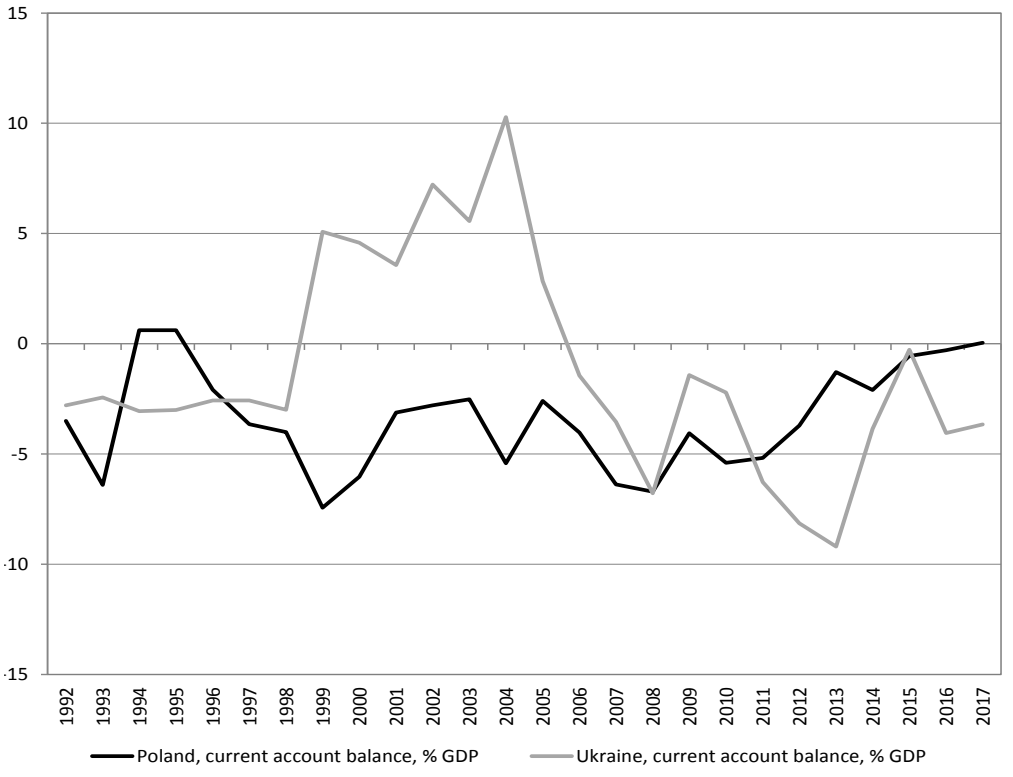

Fig. 2. Current account balance Ukraine vs. Poland during1992-2017 (Source: WEO database, IMF)

demand and export competitiveness, have been the cause of the exchange rate regime.

To better understand the undesired slow development of the economy of Ukraine, it is necessary to distinguish the processes which drive economic growth and the ways how macroeconomic policies (fiscal and monetary) interact with these processes. The aggregate demand for products and services within a country consists of domestic consumption, exports, and government expenditures. It is important to consider the interrelationships between different sectors of the economy as it progresses using a modern dynamic tool of system dynamics modelling [11]. This paper proposes the hypothesis that in an economy without direct governmental interventions, economic growth is mainly stimulated and controlled by two reinforcing and four balancing feedback loops, as described in Figure 3:

1) Reinforcing feedback loop R1 'Domestic market', in which growth of aggregate demand in the country leads to increased employment, which increases aggregate wages. When aggregate wages increase, so does the domestic consumption (assuming the share of domestic savings remains the same). An increase in domestic consumption then leads to a higher aggregate demand, which closes the feedback loop.

2) Reinforcing feedback loop R2, which shows the indirect effect of an increase in employment on the average wages within the country. When employment increases relatively to the size of the labor force, it puts upward pressure on wages, which increases aggregate wages. The strength of this feedback loop depends on the size of the labor force and the current level of employment within the country. postulates the hypothesis that many of the other economic problems in Ukraine, such as a low aggregate 


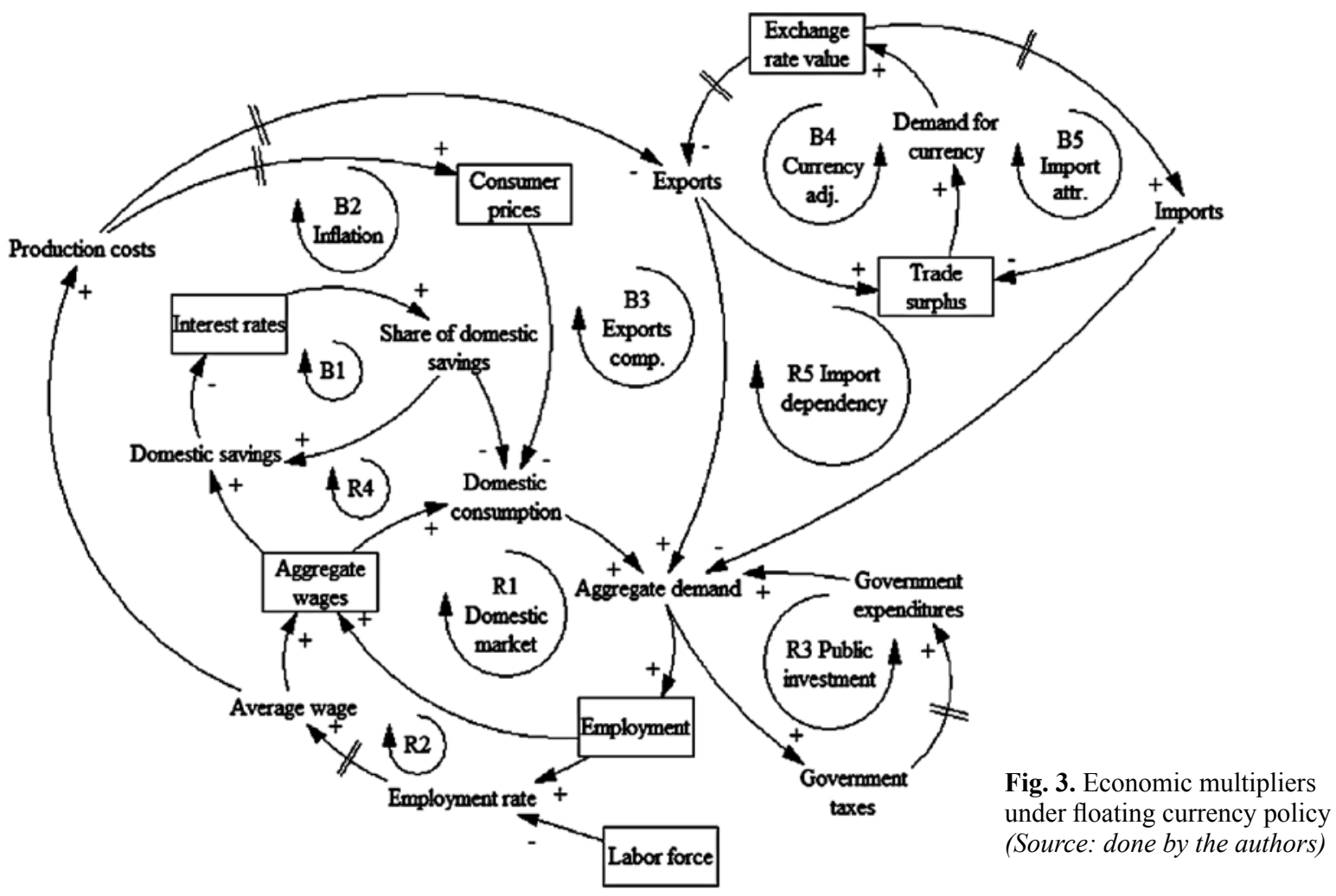

3) Balancing feedback loop B2 'Inflation', in which a growth in the aggregate wages increases the production costs for companies* (the effect depends on their labor-intensity). When production costs increase structurally, companies will decide to charge high prices for consumers. Higher consumer prices puts downward pressure on consumption, which then closes the balancing feedback loop as aggregate demand decreases employment.

4) Balancing feedback loop B3 'Export competitiveness', in which a growth in the average wages increases the production costs, which then decreases the attractiveness of exports. Over time, companies will start to look for more financially attractive import alternatives. This will decrease aggregate demand in the country which again puts downward pressure on wages, making exports more attractive again.

5) Balancing feedback loop B4 'Currency adjustment', in which increasing exports lead to a higher trade surplus for the country. A trade surplus means that more countries want to buy products and services in the currency of the country, which increases demand for its currency. A higher demand for the currency increases the exchange rate of the domes-

* The model assumes constant productivity of labor. When wages increases, companies will look for ways to increase labor productivity. This will put downward pressure on employment, which then decreases aggregate wages (balancing feedback). tic currency. A higher exchange rate makes it more expensive for other countries to import from the country, which puts downward pressure on exports.

6) Balancing feedback loop B5 'Import attractiveness', in which a higher exchange rate leads to more imports, which decreases the trade surplus and thereby puts downward pressures on the exchange rate.

When a country, such as Ukraine, intervenes directly into the economy by introducing a fixedexchange rate policy, it disturbs the natural reinforcing and balancing processes within the economy. This paper proposes the hypothesis that in an economy where the government introduced a fixedexchange rate policy, economic growth will be influenced through the interactions described in Figure 4:

1) A fixed-exchange rate decreases the strength of reinforcing feedback loop B3 'Export competitiveness'. As can be inferred from the figure, export competitiveness is mainly driven by production costs and the relative exchange rate of the country. When Ukraine introduces a fixed-exchange rate that is higher than the exchange would normally have been based on market demand for the currency, the exports of the country become less attractive for importers in other countries. Decreased exports mean that aggregate demand is lower than it would otherwise have been. 


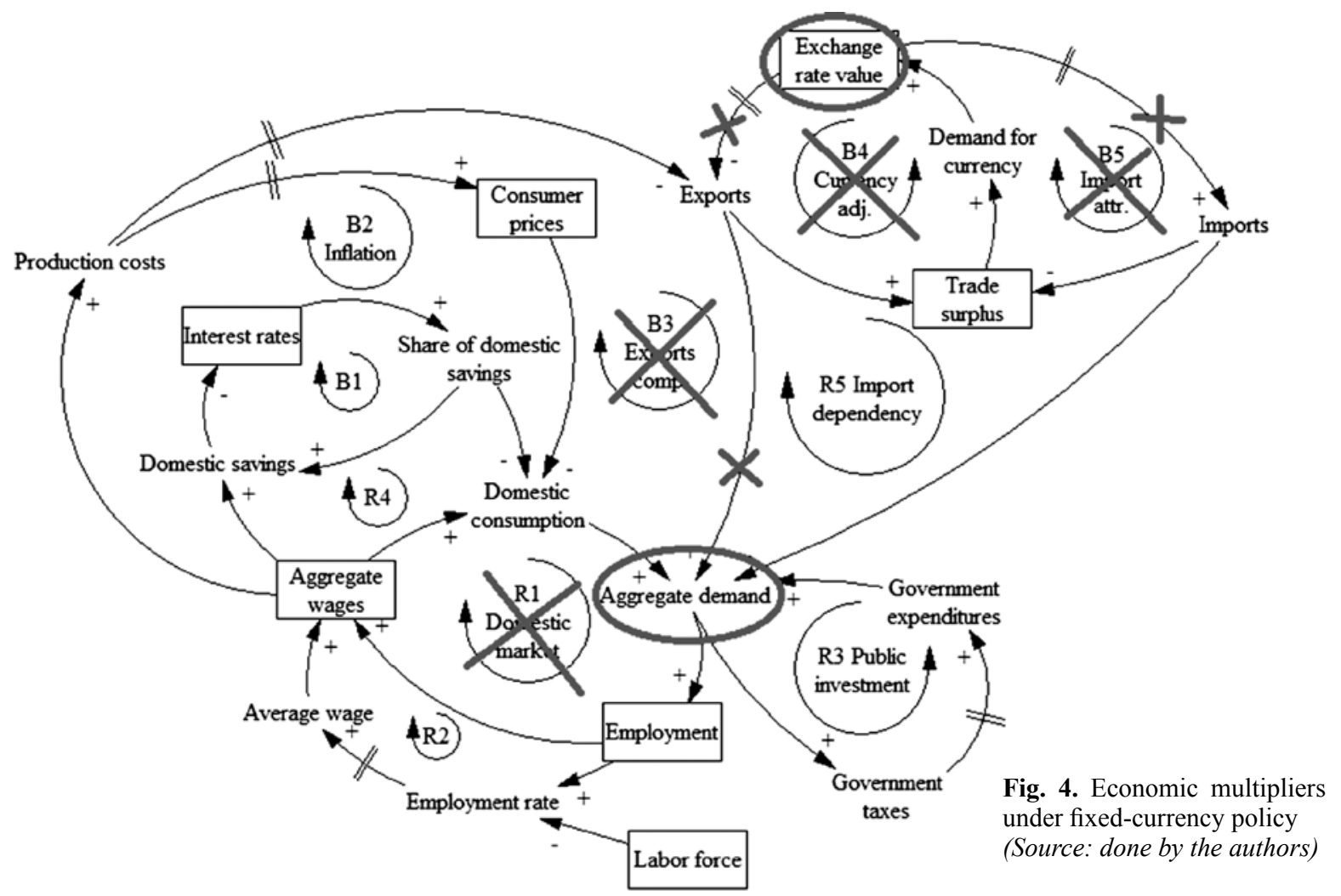

2) Through decreased aggregate demand, the fixed-exchange rate decreases the strength of the domestic market feedback loop (R1) since it puts downward pressure on wages, which decreases domestic consumption.

3) A fixed-exchange rate leads to the elimination of the currency adjustment (B4) feedback loop, which is the balancing mechanism needed to stabilize the trade surplus/deficit. Without a currency value, which reflects the competitive position of the country's economy, there will be no incentive for increased exports to balance the trade surplus/deficit.

4) A fixed-exchange rate leads to the elimination of the import attractiveness (B5) feedback loop, which under normal conditions makes imports less attractive when the exchange rate value decreases because of a decreasing competitive position of the country. With a fixed-exchange rate, it will remain attractive for domestic consumers and companies to import products and services abroad. This dampens the growth of the domestic market, as the money is not spent on domestic products and services.

For many years Ukraine pegged its exchange rate to that of the US\$ mainly because of political populism and in order to protect against the risk of currency volatility on the costs of energy imports from Russia. Following the model as presented above, it might be argued that the peg of the hryvnia to the US\$ might have been too high, considering the competitive position of the Ukrainian economy. With ending the exchange rate policy following the revolution of 2014, the value of the hryvnia rapidly declined. It is unsure how much of this fall was the cause of the political unrest and how much of the structural overvaluation of the hryvnia under the peg to the US\$ since the 2000s.

Assuming that the currency had been overvalued under its peg to the US\$, the policy could have been an important factor in the structural problems within the Ukrainian economy, mainly through a low aggregate demand (caused by low exports and high imports). This hypothesis seems to be strengthened by the fact that, after the major devaluation of the hryvnia in 2014 and 2015, export competitiveness rapidly increased. The largest part of the improvement of the trade balance came through correction of imports, which led to reorientation to domestic production.

Ukraine now has both low production costs (low wages) and a weak currency. Add to this Ukraine's high-potential society with young, English-speaking, highly educated, and ICT-minded workers, and there seems to be a high unfilled potential for increased exports and foreign investment in the country in the years to come. Another beneficial factor is the free trade agreement between the European Union and Ukraine, which has become active 
since January $2016 *$. The good thing about this agreement is that it stimulates Ukraine to focus on more high-value products and services on which no import duties are imposed, as opposed to agricultural commodities, which are still facing import quotas for the EU internal market to protect the EU agricultural sector**.

While the devaluation of the hryvnia is boosting exports, at the same time it is reducing the attractiveness to import products and services, because they have become many times more expensive. In the long term, Ukrainian companies will look for local substitutes for these imported products, which will increase domestic production and will boost the aggregate demand. However, as such alternatives do not exist in the short term, it could lead to negative effects for both local companies and consumers who still have to import their products and services from abroad. This is one of the major reasons for the inflation which followed the rapid devaluation of the hryvnia and led to a loss of purchasing power for employees who already had a very low average wage. Another reason is that inflation expectations, especially for households and companies, are coupled to the currency devaluation, forcing companies to raise prices for their goods.

Following the dynamic hypothesis as presented in this paper, increased exports will lead to a higher aggregate demand in Ukraine. At the same time, decreased imports will lead to a high diversity of local products and services to replace imports from abroad. This will also add to the aggregate demand. When the aggregate demand starts to increase, it will increase employment opportunities, which will, over time, as the employment rate increases, put upward pressure on wages. As wages increase, domestic consumption will play a more important role within the Ukrainian economy, as a balance against being too much dependent on exports. This is the way in which Poland, through (infrastructural) funds from the EU and access to its internal market, has become a major economy in the last decade, boosting both a large domestic market and a competitive export industry. As Polish economy remains on the current track, it can be expected that its average wages and its currency, the zloty, will gain in value. Following the hypothesis as presented in this paper, this will mean exports

\footnotetext{
* The agreement was already partially adopted in 2014, when the EU applied the provisions of the FTA for Ukraine unilaterally.

** Ukraine can still export larger volumes than in quotas, but in that case they have to pay a regular import duty.
}

become less competitive, while imports get more attractive. In this case, it might become more attractive for Polish companies to move some of their businesses to Ukraine, where wages are still lower and the exchange rate is attractive for exports.

Conclusion and implications for economic policymaking. Since the revolution in Ukraine in 2014, many structural reforms have been implemented, which can be expected to give a boost to economic growth. These reforms mainly revolve around decreasing the bureaucratic process, which hinders the ease of doing business within the country. Additionally, large-scale privatizations of government enterprises can be expected to increase competitiveness of these companies, while giving the government additional budget to continue further reforms. A third important reform is related to the energy market, where the government decided to cut energy subsidies which cost about $10 \%$ of GDP. This meant that gas tariffs for domestic consumers, which used to be subsidized, have increased by at least four times. While this reform was necessary, it most likely has had some negative consequences for the economic growth in the short term.

Since, as discussed above, consumers are already facing a lower purchasing power because of higher import costs, their purchasing power declines ever further through the increase in spending on the natural gas bill. This has led to inflation in Ukraine and has had a dampening effect on domestic consumption and thereby lowers the aggregate demand. This should be a primary concern for economic policymakers in Ukraine, whose top priority should be to stimulate local businesses to provide affordable alternatives to the major import products and services that have become more expensive. Compared to Poland, Ukraine's economy is more open, with an exports-to-GDP ratio of $53 \%$, compared to $50 \%$ in Poland, and imports-to-GDP ratio of $55 \%$, compared to $47 \%$ in Poland. This means that Ukraine is more dependent on imports than Poland, and this is mainly because the structure of Ukraine's domestic production is much less diversified than in Poland.

A second important policy for the Ukrainian government should be to increase its spending on large (infra)structural projects. Such projects will improve the size and quality of the domestic infrastructure, which is needed to realize the export potential thar has become within reach due to the devaluation of the hryvnia. Within Ukraine, most 
of the older infrastructure has depreciated by at least $75 \%$, while commercial harbors, warehouses, and roadways will need improvement to increase trading volumes [9]. The large government-initiated projects will also boost employment through the aggregate demand. This will help to increase domestic consumption and the size of the domestic market.

It can be expected that increased employment will put some upward pressure on average wages, but they will most likely remain competitive compared to wages in other producing countries. The wage increase will have a positive effect on increasing purchasing power, thereby reducing the potential for public discontent or domestic recession. To realize the structural investments, help will be needed from institutions like the European Union, the IMF and/or the American government. In this way, the model becomes similar to the way in which Poland was able to realize rapid economic growth through access to the structural EU investment funds which improved the quality of its exports, employment, and its domestic market.

\section{Remaining challenges and risks for fulfilling Ukraine's economic potential}

Although Ukraine's economic future seems very bright, there are still many challenges and risks which could inhibit realization of the potential. The most important internal risk is corruption and the current oligarchic structure of the economy. After gaining the independence from the Soviet Union in 1991, many of the country's key industries, such as energy, heavy industry, banking, and mining, were taken under the control of Ukrainian oligarchs.
These oligarchs, having strong ties within the government, have created a political and business environment of corruption and created a bureaucracy, which makes it difficult for small and medium sized companies to challenge the incumbents. This is also one of the major reasons why the Ukrainian economy has a very low diversity in products and services.

Some of the leading Ukrainian experts recommend the Ukrainian government to focus on «joint development and implementation of a large-scale plan to support entrepreneurship in Ukraine based on the German (1950s) and Polish (1990s) experience" [5]. Additionally, the government can decide to impose "high custom rates on raw materials and low-tech commodity exports, and minimize such costs on exports of high-tech products, and exempt from duties the import of industrial and scientific equipment to Ukraine" [5, p. 44]. The most important external risk is a prolonged or extended conflict within the country's boundaries. The loss of control on the Crimean Peninsula and the Eastern (Donbas) regions of Ukraine has a large impact on Ukrainian economy. The Donetsk and Lugansk regions in Eastern Ukraine make up roughly $15 \%$ of total GDP and $20 \%$ of the industrial output.

Some other risks are largely outside of the control of the Ukrainian government. The main one is the political developments within the United States, the European Union and China, where protectionist policies are being increasingly pursued, as opposed to international cooperation. However, even when this might continue, there are other countries who would be interested to increase cooperation with Ukraine, given its strategic location and a large amount of resources.

\section{References}

1. Faryna, O. (2015). The analysis of currency exchange rate formation in Ukraine. Scientific papers NaUKMA. Economics, $172,85-90$

2. Gorodnichenko, Y., \& Schnitzer, M. (2013). Financial constraints and innovation: Why poor countries don't catch up. Journal of European Economic Association, 11, 11151152 .

3. Lukianenko, I., et al. (2017). System analysis of state policy development during macroeconomic destabilization. Kyiv: NaUKMA. Retvieved from http://ekmair.ukma.edu.ua/handle/ $123456789 / 12348$.

4. Lukianenko, I., \& Dadashova, P. (2016). Monetary and Fiscal policies interaction in Ukraine. Actual problems of economics, 5 (179), 295-307. Retvieved from http://eco-science.net/ downloads.html.

5. Melnychuk, V. (2016). Creative destruction: From poverty to prosperity in a nation-state with an open society. The Ukrainian Week: The Discreet Charm of Ukrainian Elite, 30-45.
6. Nikolaychuk, S., \& Shapovalenko, N. (2013). The identification of the sources of current account fluctuations in Ukraine. EERC Research Network, Russia and CIS. Working paper No 13/12E.

7. Petryk, O. (2006). History of Monetary Development in Ukraine. BankIKredyt, 37, 3-24.

8. Roland, G., \& Gorodnichenko, Y. (2017). Culture, Institutions and the Wealth of Nations. Review of Economics and Statistics, 99, 402-416.

9. Shavalyuk, L. (2016). Potential at land's edge: How are Ukraine's ports changing the way they operate and what are their future prospects? The Ukrainian Week: Playing Monopoly, 26-28.

10. Skrypnychenko, M., et al. (2015). Models for identification of macroeconomic disbalances in Ukraine. Institute for economics and forecasting. National Academy of Sciences of Ukraine.

11. Wheat, D., et al. (2013). System dynamics models: the main steps of the system dynamics models elaboration with iThink 10 Software. National university of "Kyiv-Mohyla academy". 
Токарчук Т. В., Бартелет X. А.

\title{
ЕКОНОМІЧНИЙ ПОТЕНЦІАЛ УКРАЇНИ: МАКРОЕКОНОМІЧНІ МУЛЬТИПЛІКАТОРИ ТА ЗВОРОТНІЙ ЗВ' ЯЗОК
}

\begin{abstract}
Метою дослідження є емпіричний аналіз ключових факторів макроекономічної стабілізації та потенційного зростання украӥнської економіки, а також застосування методів системної динаміки для підтвердження гіпотези про те, щчо деякі початкові економічні проблеми украӥнської економіки, зокрема незначний сукупний попит та експортна конкурентоспроможність, були пов'язані з режимом обмінного курсу. В процесі дослідження було використано методи узагальнення, систематизації та групування даних, загальнонаукові методи системного аналізу та синтезу, а також методи та моделі системної динаміки.

Результати роботи. На основі проведеного порівняльного статистичного аналізу особливостей становлення та розвитку украӥнської економіки та економіки Польщі, як краӥни колишнього пострадянського простору, щзо за своїми початковими умовами була найбільш наближеною до України, підтримано гіпотезу, щзо значна кількість економічних проблем України, зокрема незначний сукупний попит і слабка конкурентоспроможність експортної продукцї, були пов'язані з режимом валютного курсу. Цю гіпотезу було підтверджено й емпірично, на основі розробленої моделі системної динаміки, яку було застосовано для прогнозування та сценарного аналізу щзодо визначення найбільш ефективних факторів макроекономічної стабілізації та потенціийного зростання української економіки у довгостроковій та середньостроковій перспективах за різних можливих початкових умов, а також можливих зовнішніх та внутрішніх ризиків.
\end{abstract}

Результати дослідження можуть бути використані державними органами для формування економічної політики та стратегії макроекономічної стабілізаиї $і$ підвищення конкурентоспроможності, а також змічунення економічного потенціалу в середньостроковій та довгостроковій перспективах.

Результати иүієї роботи є переважно пошуковими та потребують подальших глибших досліджень, перш ніж висновки могли б бути використані державними органами для розробки економічної стратегіï, щзо призведе до покращення економічного потенціалу України у короткостроковій та довгостроковій перспективі.

Висновки. Базуючись на результатах проведеного емпіричного аналізу на основі двох версій розробленої моделі системної динаміки, яка враховувала складні нелінійні динамічні взаємозв 'язки та можливість структурних перетворень з особливим фокусом на пояснення залежності між внутрішнім споживанням, сукупним попитом, інфляцією, конкурентоспроможністю експорту, змінами валютного курсу тощзо, було виявлено, щзо, незважаючи на те, шуо режим фіксованого валютного курсу свого часу мав позитивний ефект на імпорт енергоносіїв, він спровокував значну кількість негативних економічних проблем для української економіки, зокрема низький сукупний попит, низьку конкурентоспроможність експорту тощяо. Було емпірично підтверджено, щио перехід до запровадження режиму гнучкого валютного курсу, попри проблеми в короткостроковій перспективі, є одним із важливих драйверів для зміцнення економічного потенціалу, підвищення конкурентоспроможності та макроекономічної стабілізації української економіки, особливо в довгостроковій перспективі. 